\title{
Charity, Philanthropy, Public Service or Enterprise: What are the Big Questions of Nonprofit Management Today?
}

Roger A. Lohmann

West Virginia University, roger.lohmann@mail.wvu.edu

Follow this and additional works at: https://researchrepository.wvu.edu/faculty_publications

Part of the Business Administration, Management, and Operations Commons, Public Administration Commons, and the Public Policy Commons

\section{Digital Commons Citation}

Lohmann, Roger A., "Charity, Philanthropy, Public Service or Enterprise: What are the Big Questions of Nonprofit Management Today?" (2006). Faculty Scholarship. 791.

https://researchrepository.wvu.edu/faculty_publications/791 


\section{Charity, Philanthropy, Public Service or Enterprise: What are the Big Questions of Nonprofit Management Today?}

Roger A. Lohmann

West Virginia University

\section{Introduction}

For some people in public affairs and administration, nonprofit management represents an alternative form of public service; a career path somewhat apart from a career in government service. For others, nonprofit management is a relatively narrow interest growing out of the historical development of service contracting with the nonprofit sector - that rather amorphous entity consisting currently, we are told, of about 1.4 million nontaxed entities, 825,000 of which are 501 (c) 3 corporations, together with about 70,000 foundations (Smith and Lipsky, 1992; Lohmann and Lohmann, 2002, 453-468; NCCS, 2006). For others, nonprofit management is a deliberate career path, and for a relatively smaller number, voluntary action (aka community action or community development) is a calling - an opportunity to make a difference in the world.

This essay takes a birds-eye view of the topic of nonprofit management, looking at what I see as the "big issues" in nonprofit management today.

\section{Sector of What?}

My first 'big question' is what exactly is 'the third' a sector of? Society? Polity? Economy? Nation? Culture? All (or none) of the above? Perhaps the most common answer to this question in third sector studies today is that the third sector is a cluster of tax-exempt/ tax deductible organizations that together constitute civil society and can be contrasted with 'market' and 'state' organizations. I and many others find this answer problematic on a large number of fronts. My own answer comes in the form of an assertion 
that the notion of a 'nonprofit sector' of tax-exempt, tax-deductible organizations properly belongs in a more expansive vision known as the social economy. This model was articulated more than a century ago by French scholars, offered up several times recently by French and Canadian scholars, is thriving in several other domains but is still not widely recognized by nonprofit scholars in the U.S. In its canonical European form, the social economy refers to the totality of nonprofits including foundations, together with cooperatives, 'mutuals' or membership associations. (See Quarter, 1992; Quarter, Mook and Richmond, 2003)

A distinctive U.S. version of social economy, comparable in all important respects to the international view, is already a legal and institutional reality; inherent in the various sections of the U.S. Tax Code from 501 (a), through (d), including the roughly two dozen variants of Section 501 (c), as well as Section 528 and a few other choice locations. All together, the IRS descriptive information on its public charities and nonprofits web pages mentions 60 distinct types of organizations. (www.irs.gov/charities/index.html) These provisions of federal law are reinforced by and interact with state incorporation statutes and tax codes and the assorted references of a number of other federal, state and local codes and regulations. Taken together, they clearly outline a U.S. social economy, of which what the code calls 'public charities' and 'foundations' are important, but not exclusive, components. In light of existing policy, does it make sense to continue to focus on only two of this large and interrelated set of perhaps three dozen defined categories of nonprofit entities, and to call them 'the nonprofit sector'? I don't believe that it does.

Surely, the nonprofit sector, as narrowly construed, is an important entity in and of itself, and also historically important in recent decades, in much the way that the steel and auto industries were in the 1940's for example, but the third sector is nothing like the sort of free-standing entity sometimes portrayed by nonprofit scholars who equate it with civil society or differentiate it alone from government and market sectors. Legally, economically, politically and socially, it is part and parcel of something larger, and that something is best termed the social economy. The fundamental reason for this is the distinctive set of economic concerns defining the appropriate and necessary legal restraints on gifts and donations and accountability and control of the pooled assets and property given - that have formed the framework of all U.S. 'nonprofit law' from the very beginning. And it is law - constitutional, corporate and charitable trust law in particular - around which the institutions, associations and formal organizations of the third sector have been formed.

In this context, we need to look much more closely at whether, by the term third sector we mean the 'natural' or spontaneous social emergents like voluntary associations and social movements of civil society--or whether, we 
mean the legal infrastructure of contracts, corporations, and charitable trusts. Is the third sector, in other words, a matter of behavioral, or of institutional analysis, or both? And, if in the highly interdisciplinary context of contemporary third sector studies the answer comes back 'both', how are we to take care to assure that each is given its proper due?

The official U.S. social economy, as it exists in the nomenclature of the tax code and other public policy, encompasses public charities and foundations, along with a variety of other forms of social enterprise. This includes cooperatives, labor unions, political parties, and other membership organizations, a variety of non-exempt advocacy activities, various 'public trusts', mutual benefit entities and an additional assortment of ventures. ${ }^{1}$

The big issue facing nonprofit management currently is whether, indeed, "the nonprofit sector" of public charities and foundations is a major conceptual category, even a "civil society" as some have suggested, and where in this scheme of things, these other organizations belong. Can it be that this broad range of legally characterized 'nonprofit' efforts including political parties and interest and advocacy groups, cooperatives, credit unions and unincorporated associations of all sorts should also be of interest?

A related, secondary question is whether the concept of "civil society" has any interest at all for nonprofit management? Or, is civil society--as currently construed--only a topic concerned with individuals ( $q u a$ citizens and civic persons) and small groups, while nonprofit management is concerned principally with organizations and corporations? I am aware that this may appear a somewhat subtle distinction, but it is the tip of a wedge that has big, bold implications for research, scholarly activity and ultimately management practice. In any meaningful current model of civil society, do board-governed corporations that have delegated significant responsibilities for their operations to part-or-full time executives and subordinate staff members in their employ even appear, much less figure prominently?

When we speak of a topic like nonprofit management to an audience of public affairs, public administration and public policy scholars and students inclined to approach this entire domain of nonprofit management as an alternative to government service or public management, the expanded vision of the social economy covers far more territory than the more limited sphere of the conventional 'nonprofit sector'.

\section{Has Entrepreneurship Trumped Philanthropy?}

\footnotetext{
${ }^{1}$ See www.irs.gov/charities/index.html. For those wishing to pursue the matter further, the entire tax code is available online at http://www.fourmilab.ch/ustax/www/t26-A-1-F-I-501.html.
} 
Another of the big issues of nonprofit management - and a direct outgrowth of the ever-present urge to be 'more business-like' - is the proper positioning for a broad array of concepts of social entrepreneurship. By this term, I mean to suggest the full range of incentive-based approaches to social improvement, and the accompanying tropes of enterprise borrowed from the business world. ${ }^{2}$ There can be little doubt that a great many nonprofit organizations - for example, hospitals - see themselves and are seen as dynamic enterprises, rather than staid, old philanthropies and see their collective activities as an industry rather than an institution.

To suggest in the current American context that the enterprise of health care is (or should be) predominantly philanthropic - literally, conducted for the love of mankind - is to risk being treated as the proverbial skunk at the picnic! It is one of the foremost tropes of enterprise today to acknowledge that health care is an industry and treating the sick is a business. Much the same may be said for a range of other fee-based social services, and other public charities. Current management thinking in public administration and related management disciplines is doing a great deal to advance these ideas. And, in general, the larger the enterprise - the more people and money involved - the more likely it appears that the enterprise model and entrepreneurial visions have supplanted more traditional models of philanthropy.

The big issue this poses for nonprofit management is whether there will be a place remaining in this increasingly entrepreneurial world for the non-incentive based, and non-financially viable activities, and what that place will be. Accounting standards and model nonprofit statutes have already been revised to reflect these changes. Where, in a world of enterprise, is one to find a place for obligation and philanthropy? This is a very large question, indeed.

\section{What is Nonprofit Organization?}

I would also like to note briefly another important definitional concern. It is a relatively routine matter in contemporary nonprofit research to refer to "nonprofit organizations" as if there were something recognizable, homogeneous and distinct in the ways in which people organize themselves

\footnotetext{
${ }^{2}$ It is consistent with the notion of three sectors to differentiate three principal motivational patterns as well: incentive-based approaches - roughly, expectations of rewards as motivation can be distinguished from the rules-based approach of the ideal type of Weberian bureaucracy with the deontological 'rewards' of duty (including the duties of charity) and the relations-based approach of the ideal type of the commons with the interpersonal rewards of stewardship and philia, often translated as fellowship, 'civic friendship', or philanthropy, in the most extreme case, love of mankind.
} 
under nonprofit corporate and tax-exempt auspices. I would ask whether, in the instances most frequently studied - nonprofit health care, and social service settings and "private" schools and universities - this is the case, or if we have not yet gotten to the real nature of these organizations, sociologically, politically or economically.

The real question in the case of the ordinarily conceived nonprofit sector of 501 (c) 3 and 501 (c) 4 organizations is whether a legal contingency the fact that a class (or several classes) of nonprofit organization in the U.S. social economy must strictly observe particular nondistribution constraints as defined by the IRS in order not to pay corporate income taxes and to accept tax-exempt donations - is sufficient grounds on which to define a type of organization. Much of the literature of nonprofit studies is written as though the answer were unequivocally affirmative. Yet, details about the nature of this distinctive form of organization are somewhat scanty, and, as functioning organizations, most nonprofits look a great deal like ad hoc blends of main street business offices and government bureaus.

This is not a criticism the relatively large number of organizational analyses - including well-known works by Bielefeld and Galeskowitz (1997), which focused on management strategies, Smith and Lipsky (1992), which focused on purchase of services, Anthony and Young (1984), which focused on management control, or multiple works by Lester Salamon and Helmut Anheier, which focus in general on what I would call the characteristics of "thirdness." These and literally dozens of other studies of nonprofit organization, all make interesting, useful and valuable contributions. But, do they clearly and convincingly make the case for 'the nonprofit organization' as a distinct and recognizable organizational form?

It is relatively easy to suggest that they do not. They do not give us a clear picture of a distinctive 'nonprofit organization', but instead suggest a kind of opportunistic bureaucracy, combining in some unspecified, ad hoc ways, the incentives of the firm with the rules (or policies) of the bureaucracy. In other words, the nonprofit organization of the present is a hybrid. Almost all of the 'nonprofit organizations' I am aware of, by which I mean nonprofit hospitals, clinics, colleges, schools, and a vast array of social services from adoption agencies to work programs, incorporated in their states, governed by volunteer boards and managed by careerist and professional managers, look very much like neo-Weberian bureaucracies operating under such ad hoc mixtures of rule-based (or "policy-based") and incentive-based regimes. Perhaps they are most analogous to the mule. Is a mule a unique animal? Yes, it is a limited form of uniqueness. Formed from the union of a horse and a donkey, mules are sterile and incapable of reproducing their own kind. One can only wonder how far the mule analogy will hold: In particular, can this form of 'nonprofit organization' survive and reproduce beyond the social circumstances (most notably government contracting) that gave rise to it? 
Nonprofit management across numerous disciplines continues to restrict our attention and practice to an overly narrow and limited range of organizational possibilities (Lohmann, 1990). This should be an issue of major scholarly and theoretical concern, for presently, all that the future of the third sector appears to holds is more opportunistic bureaucracy within the regime of interest-group liberalism or 'private government'.

As long as we cling to the false view that only 'nonprofit organizations' consisting of rule- and incentive-driven bureaucratic hierarchies can be practical, efficient and effective, a vast range of highly interesting alternatives, variations and possibilities will continue to allude us. Everything from flat hierarchies, to feminist organizations, groups, networks, associations, orders, movements, and open spaces and many, many other organized alternatives will continue to be shunted aside or downplayed in the name of good management, as unwise and impractical. Make no mistake: These forms will continue to happen, but they will do so beyond the theoretical reaches of our research and theory, or treated as anomalies. Many of us who have seen alternative possibilities will continue to regard this as sad and unfortunate.

\section{Can We Achieve Philanthropic Sufficiency?}

Yet another big question is located squarely within the traditional world of philanthropy. To understand it fully requires just a bit of background. A modern doctrine we might call public philanthropy has been an article of neoconservative faith for most of the past century. It has emerged most recently as an alternative to, and rival of, the welfare state.

This is the seemingly widespread belief that the public (governmental) sector should be as small as possible, and taxes as low as possible. As a result, important matters of public concern like the care of the poor, the mentally ill, the old and the weak are no longer regarded as suitable subjects for public engagement, except insofar as policy relegates their care to nongovernmental 'voluntary' organizations.

To several generations of progressives, including Jane Addams and Teddy Roosevelt, limited government and large doses of voluntary action were articles of faith. Although the historical record has been considerably glossed over of late, New Deal liberals and welfare statists from FDR to Walter Mondale also gave what they believed was proper homage to this doctrine of limited government. The American public sector, even at its largest and most expansive, has never accounted for more than a small fraction of the entire U.S. economy. Old order conservatives, however, were unrelenting in their commitment to their belief that any governmental public sector was too large ( Cornuelle, 1965). They have been joined in this view in 
recent decades by a mix of modern libertarians, social conservatives and others to form a 'neo-conservatism' that arose in reaction against the Great Society and endorsed nothing short of the withering away of the state (a phenomenon characterized by a wide range of political labels and slogans from "privatization" to "starving the beast" and "compassionate conservatism").

In the hands of political leaders like Presidents Reagan and G.H.W. Bush, a key provision of this visionary transformation was a doctrine we can call philanthropic sufficiency: The claim that voluntary action - private giving and volunteer labor for the public good - offer a sufficient and politically preferable way of dealing with the social problems the Progressives steered toward government. This doctrine has never been far from the surface in the last several decades and resurfaced during recent Presidential campaigns in the form of the slogan, "compassionate conservatism" and in the "faith-based services" initiative.

This neo-conservative political doctrine was neatly encoded in the INDEPENDENT SECTOR mantra first unveiled in 1987: Give Five. The exact formula for philanthropic sufficiency encoded in that slogan combines targeted donations of five percent of personal incomes in the form of donations and five hours a week spent volunteering. It was implied that this would be sufficient to achieve the neoconservative dream of a society combining low taxes and high levels of philanthropy. This offers, on the whole, a modest alternative to the proverbial tithing, of biblical proportions that set the level of giving twice as high - one tenth.

However, the reality is that despite more than 25 years of a variety of public policy initiatives based on the presumption of philanthropic sufficiency the nonprofit sector has not been able to pick up the slack. As the final phrase on the IS "Give Five" webpage now notes, "The nonprofit sector cannot take the place of government programs, nor can it single-handedly cure the ills and disparities of society." 3 The main reason that this appears to be so is that we continue to exist in what might be termed a steady state of philanthropic insufficiency; the aggregate level of private giving in the U.S. remains currently just under two percent, and has never risen above half the IS target - one fourth of the historic tithe. Moreover, there is no sign it will do so anytime soon.

The big questions this raises can be addressed in a number of different ways. In our highly partisan time, "blue" liberals will interpret this as a failure of neoconservative doctrine, and "red" neo-conservatives will respond in kind. For the practice of nonprofit management, however, the issue is whether and how it may be possible to break the glass ceiling of

3 http://www.independentsector.org/give5/givefive.html 
philanthropic insufficiency and generate aggregate giving greater than 2 percent.

\section{Are We More Business-like Yet?}

Everyone connected with nonprofit management at one time or another comes into contact with business people who will offer, in all seriousness, the suggestion that nonprofit organizations need to be more business-like. Currently, I encounter this most frequently in the form of young scholars in schools of business who submit manuscripts to Nonprofit Management and Leadership that begin with a stock introduction informing readers that nonprofit management has much to learn from the superior insights of business management. Never do they acknowledge that there is an opportunity for reciprocal learning, with which I agree heartily; only that nonprofits have much to learn. Non-business school reviewers regularly retort with references to Enron, which before its collapse had been named America's Most Innovative Company six years in a row.

In most instances, what constitutes being "more businesslike" is relatively innocuous and common-sense advice suggesting little more than strictures to: be instrumental and goal oriented, and prudent with scarce resources; to act wisely and try not to do stupid or foolish things. In many instances, good, common sense suggestions flow from this. It is astounding to many of us, for example, how many nonprofit managers at any given moment haven't the vaguest concept of the time value of money, how to do a budget, or the elementary insight that sometimes doing one thing means you cannot do another (i.e., that opportunity costs exist).

However, the advice to be more business-like in nonprofit management, while usually good, can also be extraordinarily bad advice. In at least one instance, there is mounting evidence that has been published in both Nonprofit and Voluntary Sector Quarterly and Nonprofit Management and Leadership and several other places that the conventional, business-like, wisdom is not only wrong, but dangerously so. (Tuckman and Chang, 1991; Greenlee and Trussel, 2001; Trussel, 2004 )

The advice usually given is some form of: Nonprofit managers, keep your administrative costs (aka overhead or indirect costs) as low as possible, and always under $10 \%$. Ditto for fundraising costs. For the largest nonprofits hospitals and colleges, and a few of the largest social services, for example this is generally a pretty easy standard to live by. Managers of small nonprofits have recognized the basically suicidal nature of such prescriptions. 


\section{Will We Pay More Attention to the Advice or the Evidence?}

When considering this question, another question also arises. That is whether research evidence - not will o' the wisp flights of fancy, ideology or fashion, but good, hard, solid empirical evidence - can ever really genuinely guide management practice in nonprofit settings? Keeping your overhead costs low is one of the most durable myths of nonprofit management particularly among business-oriented board members and funding sources One can easily find evidence of this belief scattered widely: In the quibbling attentions of board members over office supplies or telephone costs in the agency budget, to the protestations of foundations that they "will not pay overhead" for certain grants. It is even found inscribed in legislation: The Older Americans Act, for example, solemnly mandates that no more than $8 \%$ of the cost of Title III aging services may be expended on administrative costs.

The implication of such well-meaning advice is clear, and closely related to the philanthropic sufficiency argument above: If only malingering managers and self-interested bureaucrats can trim wasteful and extravagant excesses, the nonprofit sector will be a better place! Yet, a growing body of research evidence affirms what most nonprofit managers already know: that advice is also dead wrong; and dangerously so. A large body of literature provides unmistakable evidence, gathered from a combined total of random samples of nearly 10,000 non-profit organizations, that low administrative costs are one of the principal predictors of fiscal distress in nonprofits (Tuchman and Chang, 1991; Greenlee and Trussel, 2001; Trussel, Greenlee and Brady, 2004; Hodge and Piccolo, 2005). The explanation for this finding is remarkably simple and common-sensical: Low administrative costs aid and abet fiscal distress in nonprofit organizations, by restricting the management capacity of the organization to deal with distress - lost grants and contracts, insufficient assets, downturns in fundraising, and the like. It makes sense, and a growing body of research evidence supports this point.

As statistical evidence goes, this may be one of the best substantiated in nonprofit studies. (Large, national random samples, no contradictory findings, etc.) Yet, 15 years after the first such finding was reported, the impact on practice has been negligible and, I predict, will continue to be so, simply because it flies in the face of not one, but two very powerful myths. The first myth has already been mentioned: that low administrative cost is an unqualified good. The second is that the impact of administrative costs is evenly distributed across all organizations. In reality, low administrative costs are much easier to achieve in large organizations, and the vast majority of nonprofit organizations are small.

Thus, the question of whether nonprofit management practice can ever really be empirically grounded is a serious question. 


\section{Will Nonprofit Boards Ever Be Well-Run?}

Now let me turn to an issue of another sort. As an editor, I am constantly struck by the number of well-meaning manuscripts that pass over my desk on the general topic of how to improve the operation of nonprofit boards of directors. Roughly $20 \%$ of all manuscripts we receive at Nonprofit Management and Leadership deal with some aspect of the topic of boards and board governance. The subject seems to hold a nearly infinite fascination for nonprofit researchers. And, I might note, another widespread myth for which anything beyond anecdotal evidence is currently lacking is that nonprofit boards are generally pretty slipshod, run-amok ventures of volunteers who don't quite measure up to the high standards of the corporate boards market where members are paid for their efforts. I wish to suggest that the question of whether or not claims about the general ineffectiveness of nonprofit boards are true - whether or not nonprofit boards are well run and effective at what they do while nonprofit boards are not - suffers from a high degree of categorical confusion.

In my view, the issue of board governance suffers from the confusion of mistaking what is inherently a political (in the Greek sense, perhaps better rendered as civic) task of governing the affairs of a nonprofit organization for a purely technical one of achieving recognizable results. One of the broader unrealized implications of what is probably the most widely cited recent work on boards - Herman and Renz' (1997) research on reality-construction in boards - is the direction in which their "social constructivism" points: Not toward relativism and away from objectivism, as some suspect, but rather away from technocracy and toward politics/civics. A political view narrowly construed is unavoidable in mediating between the outlooks, demands and expectations of multiple constituencies. What many have failed to see is that it also captures the essential character of board governance.

I recently became aware of another form of this particular categorical confusion (which is actually very pervasive today.) Annually, we take groups of graduate students to observe the state legislature and participate in the legislative process. The first and foremost impression reported from several successive student cohorts in recent years has been that the legislature could almost certainly conduct its business more efficiently and this would almost certainly result in greater effectiveness - usually defined as passage of a higher number of bills. The profoundly complex political challenge of selfgovernment by a sovereign people is, in their view, reduced to the technical challenge of adopting more bills. Is the similarly complex question of nonprofit self-governance receiving the same treatment? 
I fear we are applying much the same standards to the similarly complex issue of nonprofit governance. The legal and philosophical basis for creating nonprofit organizations can be summarized accurately as selfgovernance: An association or a corporation, whether it is organized for profit or as a nonprofit, whether it is manufacturing automobiles, delivering social services, or superintending marshlands and duck eggs, has an inherently self-governing quality that remains unchanged when the organization contracts to deliver contract services with a unit of government. The misunderstanding of the nature of state government inherent in the view that the purpose of the legislature can be measured in terms of the number of bills it passes is entirely of a piece with the technocratic view that the principal challenge of a nonprofit board is to govern more efficiently and effectively.

A part of this challenge involves discerning the external environmental demands and constraints that must be dealt with; the greater challenge (as the Herman-Renz perspective notes) involves the "internal" challenges of self-governance: mediating the environmental press of stakeholders' claims and demands into a viable enterprise. Yet, the thrust of much of our current board research is on the question of how such self-governing boards ultimately responsible only to their stakeholders - can properly satisfy standards and criteria established by external and self-appointed technical experts who simply lack standing to offer the advice they insist upon giving.

Of course it is also the case that external funding sources that wish to support a nonprofit organization have obligations and opportunities and - as a contractual condition - can specify terms of board governance, which the nonprofit is then free to accept or reject. I personally doubt, however, that this extends to the level of general knowledge, such that nonprofit educators should be assuming the role of guardians and teaching in our nonprofit management programs how each and every nonprofit board 'ought' to conduct its affairs, anymore than we should be concluding that legislatures need to become more efficient in their passage of bills.

\section{Can Accounting Information Provide Accountability?}

One of the dirty little secrets of nonprofit management concerns the general, all-purpose uselessness of nonprofit financial statements. Let me stipulate immediately that nonprofit financial statements serve well the sole elementary purpose of tracking resource flows. Thanks to the current state of the art, nonprofit managers and boards seldom misplace or fail to notice significant quantities of financial resources. Apart from this, however, for guiding the essential tasks of management, notably pursuit of mission, nonprofit financial statements are almost (but not quite) completely useless. 
Modeled after the statements of the for-profit world under the terms of enterprise accounting, nonprofit financial statements are supposed to yield true and accurate portraits of the current condition and recent changes in the value of a nonprofit organization. And in a certain, minimal, sense they do that.

All manner of courses and workshops have been mounted over the years to teach students and neophyte managers the real secrets of these esoteric documents. The real secret is that for the typical small nonprofit with assets under $\$ 5$ million, there just isn't all that much there. If you read closely you can detect subtle patterns of change in spending on salaries, rent or the phone bill. And if any of those engaged in criminal behavior or skullduggery in the organization are sufficiently stupid or careless, they will leave traces detectable in the financial statements. But you generally don't have to read nonprofit statements too closely to see that most nonprofits have a very limited range of available resources, consisting mostly of some cash in the bank, pretty shaky sources of financial inflows, some very ordinary (and tightly constrained) expenditures and very limited debt. But, if you try to get from their financial statements any real sense of where the organization stands and what it is accomplishing - what it strives to be and to do, and how well it is doing it, or any of the other real questions of accountability - you almost certainly will fail and need to look elsewhere.

Some recent work on social accounting - particularly the work of Jack Quarter, Laurie Mook and Mary Jane Richmond in Toronto and the fiscal distress research mentioned above - has attempted to massage the existing financial reporting schemes of accounting to produce more useful management information. (Quarter, Mook and Richmoond, 2003) These are certainly steps in the right direction.

There is also a variety of potentially interesting work underway on other aspects of this problem. Nonprofit Management and Leadership has published some interesting work by Gerhard Speckbacher, and will be publishing some work by a group in Holland led by Ralf Caers on the continuum of enterprise and stewardship approaches. Much more of this sort of work needs to be done before this big question of financial accountability can really be dealt with.

\section{Should Foundations Change?}

According to the latest information, there are now upwards of 70,000 foundations in the United States. Of course, only a relative handful of these account for the lion's share of assets, while the vast majority are small foundations with limited assets and highly individualized giving programs. The largest foundations have always had a major influence on nonprofit 
organizations and sectors, especially in such matters as establishing and defining the norm of program grants and their sometimes vastly exaggerated claims of their own influence on social change.

I think there are at least three big questions that we should be asking in this domain. The answers to these questions could have a profound impact on the way we do business in the nonprofit world in the future. The first is whether the case for program innovation is as strong as has been claimed in the past, or should foundations be finding different ways to award funding not involving specious claims to innovation. In particular, should these foundations with their vast fortunes be at least selectively supporting the normal everyday operations of nonprofits, and not always striving for the (increasingly bogus) claims of the "next new thing"?

A second question about foundations is certainly a big question, and somewhat more far reaching. That is the question of whether the five percent rule is still appropriate. This rule mandates that foundations spend at least five percent of their net earnings each year. Five percent was a compromise level between those who favored more and those who favored no rule at all (i.e., 0\%). Now, after several decades of experience should we be asking more questions about what has actually happened as a result of this rule, and whether continuation of the rule, or changes are justified.

A final question about foundations is the most far reaching of all: And that is whether the case for perpetual existence of foundations is a strong one. Does anyone really want the Ford Foundation or the Carnegie Corporation still orchestrating claims of innovation five centuries from now? Or, should public law and tax policy be restructured to assure that foundations spend themselves out in something like a generation or two?

\section{How Will Public Administration Be Changed By Nonprofit Management?}

Further, I would like to look at several related questions of specific interest to public administration, public management, and public affairs. The first of these questions is whether there is a legitimate public administration claim to, or interest in, nonprofit management reaching beyond the straightforward issue of purchase of services and contracting. Closely associated with that question are the related issues of whether the 'shadow state' represented by the nonprofit sector is actually a state at all, and whether 'third party governance' is actually government in any meaningful sense (Milward, 1994; Salamon, 1987; Wolch, 1990).

If public administration is going to continue and expand its interest in the broad field of nonprofit organizations and the third sector, some attention to questions such as these will be necessary. 


\section{Will Nonprofit Management Change The Relation Between Public Administration and Allied Program Fields?}

Another question which strikes me as important from my own particular vantage points involves the degree to which interest in nonprofit management can be expected to change the relation between public administration and such related disciplines as social work, health care, the arts and other disciplines and interests I would lump together here as "allied program fields." I ask this question as the holder of an MPA degree, with almost 35 years experience in social work education, more than 25 of which have been spent on the social work end of a dual-degree program with public administration that actually formed the organizational core of a newly created school. The basic question is whether there is a need to rethink the curriculum relation between public administration and other professionally oriented ventures - social work, education, health care, the arts, environmental and community development to name just a few. This is directly an issue of nonprofit management concern since so very of these involve nonprofit organizations.

\section{Conclusion}

This list of the big questions of nonprofit management, like any such list, is obviously a matter of personal preferences. Others might select some or all of these issues, but would almost certainly select others as well. Placing greater emphasis on human resources questions, for example, or on more practical matters like improved ways to locate resources would almost certainly rank higher on some lists. And I would welcome the opportunity to consider those suggestions and arguments.

The point of an exercise like this is less a matter of finding or certifying "the right answers" to the question of what are the big questions of nonprofit management. It is more a matter of the thought and discussion such openended questions provoke. Readers should consider themselves challenged to consider such questions and compose their own lists of big questions. 


\section{References}

Anheier, H. K. (2005). Nonprofit organizations: theory, management, policy. London; New York, NY, Routledge.

Anthony, R. N. and D. W. Young (1984). Management Control in Nonprofit Organizations. Homewood IL, Dow Jones.

Caers, R., C. Du Bois, et al. (2007). "Toward an agency theory for nonprofit organizations: The stewardship-agency axis." Nonprofit Management \& Leadership. (forthcoming)

Cornuelle, R. C. (1965). Reclaiming the American dream. New York, Random House.

Greenlee, J. S. and J. M. Trussel (2000). "Predicting the Financial Vulnerability of Charitable Organizations." Nonprofit Management and Leadership 11(2): 199-210.

Herman, R D. and D. O. Renz. 1997. Multiple constituencies and the social construction of nonprofit organization effectiveness. Nonprofit and Voluntary Sector Quarterly, 26, 185-206.

Lohmann, R. A. and N. Lohmann (2002). Social administration. New York, Columbia University Press.

National Center for Charitable Statistics. 2006.

Galaskiewicz, J. and W. Bielefeld (1997). Nonprofit Organizations in an Age of Uncertainty. Hawthorne NY, Aldine-DeGruyter.

Hodge, Matthew M. and Ronald F. Piccolo. 2005. Funding source, board involvement and financial vulnerability in nonprofit organizations. Nonprofit Management \& Leadership 16, no. 2: 171-190.

Milward, H. B. (1994). "The Shadow State - Government and the Voluntary Sector in Transition, by J Wolch." Public Administration Review 54(1): 7376.

Quarter, Jack (1992). Canada's social economy. Toronto: James Lorimer and Company.

Quarter, Jack, Laurie Mook \& Betty Jane Richmond (2003). What counts: Social accounting for Nonprofits and Cooperatives. Upper Saddle River, NJ: Prentice Hall.

Salamon, L. M. (1987). "Of Market Failure, Voluntary Failure and Third Party Government: Toward a Theory of Government-Nonprofit Relations in the Modern Welfare State." Journal of Voluntary Action Research 16(1-2): 29-49.

Salamon, L. M., H.K. Anheier, R. List, S. Toepler, S.W. Sokolowski \& Associates (1999). Global civil society: Dimensions of the nonprofit sector. 
Baltimore, The Johns Hopkins University Press.

Smith, S. R. and M. Lipsky (1992). Nonprofits for Hire: The Welfare State in the Age of Contracting. Cambridge MA, Harvard University Press.

Spechbacker, G. (2003). "The Economics of Performance Management in Nonprofit Organizations." Nonprofit Management and Leadership 13(3): 267-281.

Trussel, J. M. (2002). "Revisiting the Prediction of Financial Vulnerability." Nonprofit Management and Leadership 13(1): 17-32.

Tuckman, H. P. and C. F. Chang (1991). "A Methodology for Measuring the Financial Vulnerability of Charitable Nonprofit Organizations." Nonprofit and Voluntary Sector Quarterly 20(4): 445-460.

Wolch, J. R. (1990). The shadow state: government and voluntary sector in transition. New York, Foundation Center. 